\title{
KAJIAN KETERCAPAIAN STANDAR PENGELOLAAN DI SD SE KECAMATAN DEPOK SLEMAN
}

\author{
Sugiyono', Lantip Diat Prasojo ${ }^{2}$, dan Nurtanio Agus Purwanto ${ }^{3}$ \\ ${ }^{123}$ PPS Universitas Negeri Yogyakarta \\ Email: sugiyono@uny.ac.id'; lantip@uny.ac.id²; nurtanio@uny.ac.id ${ }^{3}$
}

\begin{abstract}
Abstrak: Tujuan penelitian ini adalah mengetahui (I) seberapa besar pencapaian standar pengelolaan SD di Kecamatan Depok Kabupaten Sleman, (2) faktor-faktor apa yang menjadi penghambat dan pendukung dalam ketercapaian standar pendidik dan tenaga kependidikan. Penelitian ini menggunakan metode survei untuk menggali data baik secara kualitatif maupun kuantitatif. Sampel dalam penelitian ini adalah 9 SD di Kecamatan Depok yang diambil secara purposive sampling, dengan mempertimbangkan SD klister I, klister 2, dan klister 3. Teknik pengumpulan data menggunakan teknik FGD, angket, dokumen, observasi, dan wawancara. Validitas dan reliabilitas instrumen angket menggunakan validasi ahli. Keabsahan data kualitatif divalidasi dengan model informan review, dan triangulasi data. Analisis data kuantitatif dengan teknik analisis deskriptif dan data kualitatif dengan model analisis interaktif. Hasil penelitian menunjukkan bahwa pencapaian setiap indikator pada standar pengelolaan untuk Sekolah Dasar (SD) di Kecamatan Depok Kabupaten Sleman tingkat pencapaian yang tertinggi adalah pada indikator pengawasan dan evaluasi $(90.5 \%)$, dan yang terendah adalah indikator Sistem Informasi Manajemen Sekolah (73.0\%) dan Kepemimpinan Sekolah (76.9\%). Hambatan dan usaha yang dialami sekolah dalam pencapaian Standar pengelolaan pendidikan antara lain belum adanya model standar pengelolaan, petugas pengelolaan yang sesuai dengan keahliannya belum memadai, belum mampu mengelola sistem informasi manajemen yang memadai untuk mendukung administrasi pendidikan, visi, misi, tujuan dan rencana kerja yang sesuai. Usaha yang dilakukan berkoordinasi dengan stakholder khususnya sekolah untuk membuat model pengelolaan sesuai sekolah masing-masing, mensinkronkan antara visi,misi, dan kerja sekolah, merekrut petugas pengelolaan yang mampu mengelola sistem informasi manajemen untuk mendukung kegiatan pendidikan yang lebih adaptif terhadap dinamika pendidikan.
\end{abstract}

Kata Kunci: Kajian, Standar Nasional, Pengelolaan

\section{PENDAHULUAN}

Pendidikan seharusnya menjadi wahana strategis bagi upaya mengembangkan segenap potensi yang ada pada setiap peserta didik (siswa). Siswa merupakan subyek pendidikan, bukan obyek pendidikan sebagaimana yang saat ini terjadi di kehidupan dunia pendidikan di Indonesia. Siswa dianggap sebagai botol kosong yang siap diisi dengan seabrek materi kurikulum. Pembelajaran masih banyak yang berpusat pada guru (teacher centreed learning). $\mathrm{Hal}$ inilah yang dikemudian hari menyebabkan lulusan yang tidak kritis terhadap zamannya karena siswa terbiasa menerima secara satu arah apa yang didapatnya di bangku sekolah. Siswa dipandang sebagai makhluk yang pasif yang belum memahami dan dituntut memahami materi yang disampaikan guru. Karena sifatnya sebagai objek, kesempatan siswa untuk mengembangkan kemampuan sesuai minat dan bakatnya bahkan untuk bisa belajar sesuai dengan gaya belajarnya menjadi terbatas.

Saatnya Indonesia mengembangkan pembelajaran yang lebih berpusat pada siswa (Student Centered Learning). Guru dan sekolah dengan dukungan pemerintah dan masyarakat harus dapat mengembangkan metode pembelajaran seperti problem based learning, collaborative learning, project based learning dan lain-lain. Tujuannya siswa bisa belajar lebih 
banyak, belajar menjadi lebih hidup dan belajar bukan merupakan suatu beban bagi siswa namun suatu kebutuhan, sehingga mereka bisa menjadi pembelajar sepanjang hayat (lifelong learner).

Sebagai titik acuan untuk menatap ke depan (point of departure) dapat dilihat posisi Indeks Pengembangan Kehidupan Manusia (HDI) di Indonesia pada tahun 2013 yang berada pada posisi ke 121 dari 187 negara di dunia. HDI adalah pengukuran perbandingan dari harapan hidup, melek huruf, pendidikan dan standar hidup untuk semua negara seluruh dunia. Kondisi ini masih jauh dibawah Negara tetangga dan Negara di regional Asia Tenggara lainnya seperti Singapura (18), Brunei Darussalam (30), Malaysia (64), Thailand (103), dan Filipina (I I4). Negara kita hanya beberapa tingkat berada di atas Vietnam (I27), Laos dan Kamboja (I38), Myanmar (I49). (http://www.mitrainvestor.com)

Untuk mewujudkan cita-cita luhur tesebut, pemerintah menetapkan 8 Standar Nasional Pendidikan Indonesia yang menjadi pedoman bagi Pengelolaanuntuk mengembangkan kemampuan dan membentuk watak serta peradaban bangsa yang bermartabat dalam rangka mencerdaskan kehidupan bangsa. Dalam UU No. 20 Tahun 2003, dijelaskan bahwa Standar Nasional Pendidikan adalah kriteria minimal tentang sistem pendidikan di seluruh wilayah hukum Negara Kesatuan Republik Indonesia (Pasal I Ayat I7). Standar nasional pendidikan terdiri atas standar isi, proses, kompetensi lulusan, tenaga kependidikan, pengelolaan, pengelolaan, pembiayaan, dan penilaian pendidikan yang harus ditingkatkan secara berencana dan berkala (Pasal 35 Ayat I). dengan diberlakukannya Peraturan Pemerintah Nomor 19 Tahun 2005 tentang Standar Nasional Pendidikan. Delapan Standar Nasional Pendidikan Indonesia yang dimaksud adalah: I). Standar Kompetensi Lulusan; 2). Standar Isi; 3). Standar Proses; 4). Standar Pendidik dan Tenaga Kependidikan; 5). Standar Pengelolaan; 6). Standar Pengelolaan Pendidikan; 7). Standar Pembiayaan Pendidikan; 8). Standar Penilaian Pendidikan

Namun demikian dengan dinamika perkembangan masyarakat, lokal, nasional, dan global guna mewujudkan fungsi dan tujuan pendidikan nasional maka pemerintah telah menerbitkan Peraturan Pemerintah (PP) terbaru sebagai perubahan atas PP No. 19 Tahun 2005. Pada tanggal 7 Mei 2013 lalu, Presiden Republik Indonesia, Susilo Bambang Yudhoyono, telah menandatangani sebuah peraturan baru yaitu Peraturan Pemerintah No. 32 Tahun 2013 tentang Perubahan Atas Peraturan Pemerintah No. 19 Tahun 2005 tentang Standar Nasional Pendidikan.

Dengan terbitnya PP tentang SNP tersebut, yang hingga kini telah berlaku selama sekitar 8 tahun, mendorong perlu dilakukan Studi Ketercapaian SNP, studi ini penting agar arah kebijakan untuk mewujudkan pendidikan yang berkualitas di pusat, daerah maupun satuan pendidikan dapat tercapai secara efektif dan efisien sesuai dengan perkembangan Iptek, kebutuhan, dan karakteristik satuan pendidikan dan daerah. Penelitian ini secara khusus difokuskan pada pencapaian standar pengelolaan sebagai bagian dari standar nasional pendidikan dengan mengambil kasus di SD se Kecamatan Depok Sleman.

Secara umum tujuan penelitian ini adalah untuk mengetahui ketercapaian standar pendidikan di Indonesia sejak ditetapkannya PP 19 Tahun 2005 tentang Standar Nasional Pendidikan. Selanjutnya secara khusus tujuan penelitian ini adalah untuk mengetahui: seberapa besar tingkat ketercapaian standar pengelolaan di SD se Kecamatan Depok Kabupaten Sleman, dan faktor-faktor apa yang menjadi penghambat dan pendukung dalam ketercapaian standar pengelolaan di SD se Kecamatan Depok Kabupaten Sleman.

Setiap aktivitas manajemen baik manajemen organisasi pada umumnya dan organisasi Kementerian Pendidikan Nasional khususnya, akan selalu membuat kebijakan (policy) dan perencanaan (planning). Webster (1997) menyatakan bahwa policy adalah: "wisdom in the management affairs, also definite course or method of action selected to guide and 
determine present and future decisions" Kebijakan adalah metode bertindak yang dipilih sedemikian rupa, sehingga memberi arahan dalam membuat keputusan-keputusan baik untuk keperluan sekarang maupun untuk masa yang akan datang.

Selanjutnya Rue \& Byars (2000) menyatakan bahwa policy adalah: general guide to action that direct the attainment of objectives. Policy does not tell organizational members exactly what to do, but they do establish the boundaries within which they must operate". Kebijaksanaan adalah merupakan arahan untuk bertindak dalam rangka pencapaian tujuan.Policy tidak menunjukkan secara pasti anggota organisasi untuk bertindak, tetapi hanya memberikan batas-batas (ruang lingkup) untuk bertindak. Sementara itu Coulter\& Robbins (I999) menyatakan bahwa "policy is a guide that establish parameters for making decisions". Kebijakan adalah merupakan panduan yang berupa parameter-parameter yang dapat digunakan untuk membuat keputusan.

George C Edward III (1978) memberikan definisi kebijaksanaan negara adalah "Policy is government say and do, or do not do. It is the goals or purposes of government program." Kebijaksanaan adalah apa yang dinyatakan dan dilakukan atau tidak dilakukan oleh pemerintah. Kebijaksanaan negara itu berupa sasaran atau tujuan dari program-program pemerintah. Kebijakan publik pada dasarnya adalah suatu keputusan yang dimaksudkan untuk mencapai tujuan tertentu, mengatasi masalah tertentu, melakukan tujuan tertentu, yang dilakukan oleh instansi yang berwewenang dalam rangka penyelenggaraan tugas pemerintahan negara (Mustapadidjaja, 2002: 5).

Dalam Sistem Administrasi Negara Republik Indonesia (SANRI) yang diterbitkan oleh Lembaga Administrasi Negara (199I) dinyatakan bahwa, kebijaksanaan pada dasarnya merupakan ketentuan-ketentuan yang harus dijadikan pedoman, pegangan atau petunjuk bagi setiap usaha dan aparatur pemerintah, sehingga tercapai kelancaran dan keterpaduan dalam mencapai tujuan tertentu. Kebijakan dapat dibedakan ke dalam kebijaksanaan internal, yaitu kebijaksanaan yang mempunyai kekuatan hukum mengikat aparatur pemerintah, dan kebijaksanaan eksternal, yaitu yang mengikat masyarakat.Kebijaksanaan dapat berbentuk lisan maupun tertulis.Namun untuk kepastian pelaksanaan, suatu kebijaksanaan sebaiknya ditetapkan secara tertulis.

Berdasarkan pengertian-pengertian tentang kebijaksanaan tersebut maka di sini dapat dikemukakan bahwa, kebijaksanaan adalah pernyataan seseorang atau kelompok yang berkuasa secara lisan maupun tertulis, tentang arah dan tujuan organisasi serta tindakan yang ditetapkan untuk dilaksanakan atau tidak dilaksanakan, sehingga dapat dijadikan pedoman, pegangan atau petunjuk bagi setiap usaha dalam mencapai tujuan.

Nigro and Nigro dalam Irfan Islamy (1992) tidak membedakan antara pembuatan kebijakan (policy making) dan pengambilan keputusan (decision making). "No absolute distinction can be made between policy making and decision making, because every policy determination is decision. Policies, how ever, establish course of action that guide the numerous decision, in implementing the objective chosen". Tidak ada perbedaan yang mutlak yang dapat dibuat antara pembuatan kebijakan dengan pembuatan keputusan, karena setiap penentuan kebijaksanaan adalah merupakan suatu keputusan.Tetapi kebijaksanaan-kebijaksanaan membentuk serangkaian tindakan-tindakan yang mengarahkan banyak bermacam-macam keputusan yang dibuat dalam rangka melaksanakan tujuan-tujuan yang dipilih.

Kebijaksanaan yang baik mempunyai indikator tertentu.Dengan indikator berikut setiap pimpinan unit kerja dalam membuat kebijakan dapat berpedoman dan mengarah pada indikator tersebut.Salah satu indikator kebijaksanaan yang baik adalah, bahwa dalam membuat kebijaksanaan harus didasarkan pada data yang lengkap, valid, reliabel, obyektif dan up to date.Data dengan kriteria tersebut, hanya dapat diperoleh melalui penelitian.Butir-butir indikator kebijaksanaan yang baik adalah sebagai berikut.

a. Proses pembuatan kebijaksanaan menggunakan prosedur/aturan yang telah disepakati, 
b. Proses pembuatan kebijaksanaan dilakukan secara transparan, dan demokratis dengan melibatkan berbagai komponen masyarakat yang akan melaksanakan dan dikenai kebijaksanaan tersebut,

c. Proses pembuatan kebijaksanaan berpedoman pada kebijaksanaan diatasnya, dan tidak bertentangan dengan kebijaksanaan yang setingkat,

d. Proses pembuatan kebijaksanaan didasarkan pada data yang lengkap, valid, reliabel, obyektif dan up to date,

e. Kebijaksanaan yang telah dirumuskan memiliki nilai multiply effectyang berkelanjutan,

f. Kebijaksanaan yang dirumuskan berorientasi untuk meningkatkan kesejahteraan rakyat,

g. Rumusan kebijaksanaan jelas, mudah diimplementasikan dan mudah dikontrol,

h. Kebijaksanaan yang dirumuskan feasible (memperhatikan dengan sumber daya yang tersedia),

i. Kebijaksanaan yang dirumuskan bersifat adil, tidak memihak pada kepentingan kelompok tertentu.

Seperti telah dikemukakan dalam undang-undang no 20 tentang sistem pendidikan Nasional bahwa, Pendidikan adalah usaha sadar dan terencana untuk mewujudkan suasana belajar dan proses pembelajaran agar peserta didik secara aktif mengembangkan potensi dirinya untuk memiliki kekuatan spiritual keagamaan, pengendalian diri, kepribadian, kecerdasan, akhlak mulia, serta ketrampilan yang diperlukan dirinya, masyarakat, bangsa dan Negara

Berdasarkan pengertian tersebut dapat dikemukakan di sini bahwa, penyelenggaraan pendidikan itu perlu disadari arti pentingnya, sehingga diperlukan perencanaan yang komprehensif dan sistematis, agar proses belajar dan pembelajaran dapat berlangsung optimal, sehingga peserta didik aktif mengembangkan potensi dirinya. Dengan berkembangnya potensi, maka peserta didik akan memiliki kekuatan spiritual keagamaan, mampumengendalikan diri dalam kehidupan di masyarakat, memiliki kepribadian tangguh, memiliki kecerdasan yang tinggi, akhlak mulia, serta ketrampilan yang diperlukan dirinya, masyarakat, bangsa dan Negara

Pendidikan bukan sekedar persoalan teknik pengolahan informasi, bahkan bukan sekedar penerapan "teori belajar" di kelas, tetapi menurut Jerome Bruner dalam (Saiful Sagala, 2008), pendidikan merupakan usaha yang kompleks untuk menyesuaikan kebudayaan dengan kebutuhan anggotanya, dan menyesuaikan anggotanya dengan cara mereka mengetahui kebutuhan kebudayaan. Selanjutnya dinyatakan bahwa pendidikan memiliki peran ganda dan seimbang dalam masyarakat industri, yakni memberi pengetahuan dasar dan kecakapan baru yang sangat diperlukan oleh dunia kerja serta melindungi kemajuan dan kebebasan melalui kebebasan akademik dan pendidikan individu dalam masyarakat demokratis.

Dilihat dari fungsi dan tujuannya, maka pendidikan dapat digolongkan sebagai kehidupan karena memiliki sifat untuk berubah, baik masukannya (input), prosesnya maupun outputnya. Masukan adalah segala hal (riil dan abstrak) yang diperlukan untuk berlangsungnya proses, misalnya yang riil adalah peserta didik, pendidikan dan tenaga kependidikan, pengelolaan dan dana, sedangkan yang abstrak misalnya, legalisasi dan regulasi pendidikan, kurikulum, organisasi, administrasi dan kultur sekolah tertentu.

Menurut Makmun (2003) pendidikan dapat mencakup seluruh proses hidup dan segenap bentuk interaksi individu dengan lingkungannya, baik secara formal, nonformal dan informal dalam rangka mewujudkan diriya sesuai dengan tahapan tugas perkembangannya secara optimal, sehingga ia dapat mencapai suatu kedewasaan. Pendidikan itu normative yang bersumber pada tugas-tugas perkembangan dan kriteria kedewasaan dan selanjutnya 
menemukan potensi tersebut yang berkaitan dengan suatu bakat dan minatnya Dalam arti yang terbatas, pendidikan dapat merupakan salah satu proses interaksi belajar mengajar dalam bentuk formal yang dikenal sebagai pengajaran (instructional) yang diperankan oleh guru dan peserta didik. Proses pendidikan ini akan menemukan orang berbakat dan member kesempatan memperluas dan mengembangkan dan bakatnya.

Seperti telah dikemukakan bahwa Indonesia diselenggarakan melalui jalur, jenjang dan jenis pendidikan. Jalur pendidikan adalah wahana yang dilalui peserta didik untuk mengembangkan potensi dirinya dalam suatu proses pendidikan yang sesuai dengan tujuan pendidikan. Terdapat tiga jalur pendidikan yaitu, jalur pendidikan formal, nonformal dan informal.Pendidikan formal adalah jalur pendidikan yang terstruktur dan berjenjang yang terdiri atas pendidikan dasar, pendidikan menengah dan pendidikan tinggi.Pendidikan nonformal adalah jalur pendidikan di luar pendidikan formal yang dapat dilaksanakan secara terstruktur dan berjenjang.Pendidikan informal adalah jalur pendidikan keluarga dan lingkungan.

Istilah strategi pada awalnya dipakai pada dunia militer yang diartikan sebagai cara penggunaan seluruh kekuatan militer untuk memenangkan suatu peperangan. Pengatur strategi, harus mempertimbangkan bagaimana kekuatan pasukan yang dimilikinya; misalnya kemampuan setiap personil, jumlah dan kekuatan persenjataan, motivasi pasukannya, dan lain sebagainya. Selanjutnya pengatur strategi harus menghimpun informasi kekuatan lawan, dan setelah itu baru menyusun tindakan yang harus dilakukannya, baik metode, teknik dan taktik, mauun waktu yang pas untuk melakukan serangan. Oleh karena itu dalam menyusun strategi perlu memperhitungkan berbagai faktor, baik faktor intern maupun faktor ekstern. Begitu juga seorang pelatih sepakbola, ia akan menentukan srategi yang dianggapnya tepat untuk memenangkan suatu pertandingan setelah ia memahami segala potensi yang dimiliki timnya. Apakah ia akan melakukan strategi menyerang dengan pola 2-3-5, misalnya, atau strategi bertahan dengan pola 5-3-2, semuanya sangat tergantung kepada kondisi tim yang dimilikinya serta kekuatan tim lawan (Roy Barnes, 2005).

Pandangan strategis tentang sebuah organisasi pendidikan harus mencakup pertimbangan-pertimbangan tentang tujuan dan sasaran untuk organisasi. Hal tersebut mengandung arti bahwa tujuan-tujuan dari suatu lembaga pendidikan akan mengarah pada gagasan-gagasan yang berhubungan dengan perbaikan, peningkatan efektifitas atau penelitian terhadap mutu. (Bush \& Coleman: 20I2)

Perencanaan strategis menurut Bryson (2004) adalah sebuah proses yang menghasilkan keputusan dan tindakan untuk membimbing apa program itu, apa yang dilakukan, dan mengapa melakukannya. Perencanaan strategis merupakan sebuah proses praktis untuk membantu mengadaptasi sebuah produk, layanan, dan aktivitas sesuai dengan kebutuhan masyarakat akan program tersebut. Keuntungan dari adanya perencanaan strategis meliputi peningkatan kinerja program, penggunaan sumberdaya, pemahaman terhadap konteks program, pengambilan keputusan, komunikasi dengan pengguna/pelanggan, dan dukungan politik akan program tersebut. (Bryson, 2004)

Salah satu alat analisis yang digunakan dalam perencanaan strategis pendidikan adalah SWOT. Analisa SWOT bertujuan untuk menemukan aspek-aspek penting dari hal-hal kekuatan, kelemahan, peluang, dan ancaman. Tujuan pengujian ini adalah untuk memaksimalkan kekuatan, meminimalkan kelemahan, mereduksi ancaman dan membangun peluang. SWOT dibagi dalam dua elemen, yaitu analisa internal yang berkonsentrasi pada prestasi institusi itu sendiri dan analisa lingkungan. (Sallis, 20I2).

Analisis SWOT merupakan salah satu strategi yang banyak dilakukan oleh pengembang manajemen termasuk manajemen pendidikan dalam melakukan kajian awal terhadap performansi sebuah organisasi. Sehingga dari sini akan terdeskripsikan kekuatan, kelemahan, peluang dan tantangan yang dihadapi organisasi agar memperoleh hasil maksimal 
dalam pelaksanaan program. Dalam kaitan dengan pelaksanaan program pendidikan di sekolah sudah tentu sekarang ini setiap sekolah memiliki Evaluasi Diri Sekolah (EDS). EDS merupakan bagian dari kepentingan akreditasi sekolah sehingga keberadaannya merupakan hal yang wajib. Dari evaluasi ini akan dapat diketahui kedudukan sekolah baik secara internal (kekuatan dan peluang), dan eksternal (kelemahan dan tantangan) di dalam melaksanakan program yang dikembangkan sekolah.

Di dalam penyelenggaraan pendidikan nasional pada tahun 2005 Indonesia memiliki perangkat pelaksana Undang-Undang Nomor 20/2003 tentang Sistem Pendidikan Nasional berupa Peraturan Pemerintah (PP) Nomor 19 Tahun 2005 tentang Standar Nasional Pendidikan. Di dalam PP ini didefinisikan Standar Nasional Pendidikan adalah acuan minimal penyelenggaraan pendidikan untuk seluruh lembaga pendidikan dasar dan menengah di seluruh wilayah hukum Indonesia. Selanjutnya seiring dengan perubahan kurikulum menuju penyelenggaraan pendidikan yang semakin baik agar semakin sesuai dengan kebutuhan dan perkembangan zaman, maka pada tahun 2013 Standar Nasional Pendidikan berubah menjadi PP Nomor 32 Tahun 2013, di dalam rumusannya Standar Nasional Pendidikan didefinisikan sebagai kriteria minimal tentang sistem pendidikan di seluruh wilayah hukum Negara Kesatuan Republik Indonesia.

Adanya perubahan Peraturan Pemerintah Nomor 19 tahun 2005 tentang Standar Nasional Pendidikan menjadi PP Nomor 32 tahun 2013 yang diterbitkan pada tanggal 7 Mei 2013 merupakan upaya pemerintah dalam rangka peningkatan mutu dan daya saing sumberdaya manusia Indonesia hasil pendidikan yang telah menjadi komitmen nasional. Rencana Pembangunan Jangka Menengah Nasional 2010 - 2014 menyebutkan bahwa salah satu substansi inti program aksi bidang pendidikan adalah penataan ulang kurikulum sekolah sehingga dapat mendorong penciptaan hasil didik yang mampu menjawab kebutuhan sumberdaya manusia untuk mendukung pertumbuhan nasional dan daerah". Dengan demikian pemantapan Standar Nasional Pendidikan dan pengaturan kurikulum secara utuh sangat penting dan mendesak dilakukan untuk mencapai tujuan tersebut.

Standar Nasional Pendidikan, yang diatur dalam Peraturan Pemerintah Nomor 19 Tahun 2005 tentang Standar Nasional Pendidikan perlu diselaraskan dengan dinamika perkembangan masyarakat, lokal, nasional, dan global guna mewujudkan fungsi dan tujuan pendidikan nasional. Standar Kompetensi Lulusan, Standar Isi, Standar Proses, dan Standar Penilaian; yang bersama-sama membangun kurikulum pendidikan; penting dan mendesak untuk disempurnakan. Selain itu, ide, prinsip dan norma yang terkait dengan kurikulum dirasakan penting untuk dikembangkan secara komprehensif dan diatur secara utuh pada satu bagian tersendiri.

Berdasarkan uraian teori dan definisi di atas maka strategi pencapaian program standar nasional pendidikan yang dimaksud dalam penelitian ini adalah tahapan kegiatan yang melibatkan komponen-komponen secara sistematis yang menghasilkan tindakan penting tentang pencapaian Standar Nasional Pendidikan (SNP) agar sesuai dengan kebutuhan masyarakat melalui analisis terhadap kekuatan (strength), kelemahan (weakness), peluang (opportunity), dan tantangan (treath). Sehingga berdampak pada adanya perbaikan, peningkatan efektivitas, peningkatan terhadap mutu, peningkatan kinerja program, penggunaan sumberdaya, pemahaman terhadap konteks program, pengambilan keputusan, komunikasi dengan pengguna, dan dukungan politik akan program tersebut.

Standar Nasional Pendidikan (SNP) telah mengalami perubahan, dari PP Nomor 19/2005, menjadi PP Nomor 32 tahun 2013. Namun demikian Standar Nasional Pendidikan yang diajukan baik pada PP Nomor 19/2005 maupun PP Nomor 32/20I3 jumlahnya tetap yaitu delapan standar. Hanya saja pada PP nomor 32/20I3 ada perubahan konten yang elementer pada empat standar yaitu; standar Isi, standar proses, standar kompetensi lulusan dan standar penilaian. Standar Nasional Pendidikan menurut PP Nomor 32 Tahun 2013 
tentang perubahan Standar Nasional Pendidikan dirumuskan bahwa Standar Nasional Pendidikan merupakan kriteria minimal tentang sistem pendidikan di seluruh wilayah hukum Negara Kesatuan Republik Indonesia. Ruang lingkup Standar Nasional Pendidikan meliputi; Standar Isi, Standar Proses, Standar Kompetensi Lulusan, Standar Pendidik dan Tenaga Kependidikan, Standar Pengelolaan, Standar Pengelolaan, Standar Pembiayaan, dan Standar Penilaian Pendidikan.

Berdasarkan Peraturan Pemerintah tersebut didefiniskan bahwa:I) Standar Kompetensi Lulusan adalah kriteria mengenai kualifikasi kemampuan lulusan yang mencakup sikap, pengetahuan, dan keterampilan; 2) Standar Isi adalah kriteria mengenai ruang lingkup materi dan tingkat Kompetensi untuk mencapai Kompetensi lulusan pada jenjang dan jenis pendidikan tertentu; 3) Standar Proses adalah kriteria mengenai pelaksanaan pembelajaran pada satu satuan pendidikan untuk mencapai Standar Kompetensi Lulusan; 4) Standar Pengelolaanadalah kriteria mengenai pendidikan prajabatan dan kelayakan maupun mental, serta pendidikan dalam jabatan; 5) Standar Pengelolaan; 6) Standar Pengelolaan adalah kriteria mengenai perencanaan, pelaksanaan, dan pengawasan kegiatan pendidikan pada tingkat satuan pendidikan, kabupaten/kota, provinsi, atau nasional agar tercapai efisiensi dan efektivitas penyelenggaraan pendidikan; 7) Standar Pembiayaan adalah kriteria mengenai komponen dan besarnya biaya operasi satuan pendidikan yang berlaku selama satu tahun; dan 8) Standar Penilaian Pendidikan adalah kriteria mengenai mekanisme, prosedur, dan instrumen penilaian hasil belajar Peserta Didik. (PP Nomor 32/2013). Adapun kedelapan standar nasional pendidikan tersebut dapat dijelaskan sebagai berikut. Berikut ini dideskripsikan kajian teori yang terkait dengan fokus penelitian.Karena penelitian ini merupakan penelitian kebijakan, maka teori yang dideskripsikan meliputi teori kebijakan, pendidikan, strategi pencapaian standar nasional pendidikan, standar nasional pendidikan (PTK, Isi , Proses, Pengelolaan, dan Pembiayaan), dan kurikulum 2013.

\section{METODE PENELITIAN}

Metode pengkajian ini akan menggunakan metode survei untuk mengetahui ketercapaian standar pengelolaan dan mengukur kontribusi masing-masing indikator. Selain itu, juga akan digunakan metode diskusi dalam hal ini diskusi terfokus yang digunakan untuk mengetahui komponen kekuatan, kelemahan, peluang dan tantangan dalam pemenuhan standar pengelolaan. Berdasarkan kedua metode ini akan diperoleh data dan informasi yang dibutuhkan guna menjawab pertanyaan penelitian sesuai tujuan penelitian ini. Untuk melengkapi hasil yang diperoleh dari kedua metode tersebut akan digunakan metode/studi kepustakaan berupa telaah dokumen-dokumen yang terkait dengan substansi penelitian ini seperti berkas-berkas dokumen kepemilikan pengelolaan pendidikan.

Populasi penelitian ini adalah seluruh SD di Kecamatan Depok Kbupaten Sleman. Namun karena adanya keterbatasan biaya, tenaga dan waktu, maka penelitian ini akan dilakukan pada tingkat sampel. Sedangkan sampel yang akan dipilih adalah sebanyak 6 sekolah dasar yang ditetapkan secara purposive sampling dengan mempertimbangkan kriteria SD unggul, menengah, dan kurang. Penelitian ini akan mengambil sumber data yang benar-benar mengetahui permasalahan substansi penelitian yakni sejumlah responden dan beberapa informan. Responden penelitian ini adalah para para guru di 6 SD terpilih. Adapun SD yang terpilih sebagai sampel purposive adalah: SDN Depok I, SDN Caturtunggal I, SDN Babarsari, SDN Gejayan, SDN Condongcatur, dan SDN Kentungan. Sedangkan informan penelitian ini adalah Dinas Pendidikan, dan Kepala Sekolah/Wakil Kepala bidang pengelolaan. Karena menggunakan perpaduan antara pendekatan kuantitatif dan kualitatif, maka teknik penelitian ini juga merupakan kombinasi dari keduanya. Penelitian ini akan menggunakan dua teknik untuk mendapatkan data penelitian; yaitu survei, focus group discussion (FGD). Kedua teknik pengumpulan data tersebut dapat dijelaskan sebagai berikut. 
Statistik deskriptif adalah statistik yang digunakan untuk menganalisis data dengan cara mendeskripsikan atau menggambarkan data yang terkumpul sebagaimana adanya tanpa membuat kesimpulan yang berlaku untuk umum. Teknik analisis data secara kualitatif dilakukan untuk kepentingan pemaknaan dengan menganalisis data hasil Analisis isi dilakukan terutama untuk melihat sejauhmana tingkat koherensi berbagai temuan data kuantitatif dan data kualitatif tentang program pendidikan karakter terintegrasi dengan mata pelajaran di SMK. Teknik analisis yang digunakan dalam penelitian ini adalah analisis interaktif (Miles dan Huberman, 1984: 23). Dalam model analisis ini, tiga komponen analisisnya yaitu reduksi data, sajian data, dan penarikan kesimpulan atau verivikasi, aktivitasnya dilakukan dalam bentuk interaktif dengan proses pengumpulan data sebagai suatu proses yang berlanjut, berulang, dan terus-menerus hingga membentuk sebuah siklus. Dalam proses ini aktivitas peneliti bergerak di antara komponen analisis dengan pengumpulan data selama proses ini masih berlangsung. Selanjutnya peneliti hanya bergerak diantara tiga komponen analisis tersebut.

\section{HASIL PENELITIAN DAN PEMBAHASAN}

\section{Kelayakan Sekolah Dasar di Kecamatan Depok}

Kelayakan satuan pendidikan (berdasarkan sampel 6 Sekolah Dasar di Kecamatan Depok Kabupaten Sleman) sebagai penyelanggara pendidikan bila dilihat dari segi persentase sekolah dalam mencapai standar isi, proses, kompetensi lulusan, sarana dan prasarana, pendidik dan tenaga kependidikan, pengelolaan, pembiayaan dan penilaian ditunjukkan pada table I berikut. Berdasarkan tabel I tersebut terlihat bahwa, satuan pendidikan SD yang telah mencapai antara 50 sd $60 \%$, sebanyak $0 \%$, mencapai $>60$ sd $70 \%$ sebanyak $0 \%$, mencapai $>70$ sd $80 \%$ sebanyak $17 \%$ dan yang mampu mencapai $>80 \%$ baru $83 \%$ SD. Hal ini menunjukkan bahwa pada umumnya ketercapaian standar nasional pendidikan sudah mencapai standar minimal yang ditetapkan oleh pemerintah. Sekolah Dasar di Kecamatan Depok Kabupaten Sleman termasuk dalam kategori sekolah maju dan memadai dalam melaksanakan dan menyelenggarakan kegiatan pendidikan.

Tabel I

Jumlah dan Persentase Sekolah Dasar dalam Mencapai Standar Nasional Pendidikan

\begin{tabular}{|c|c|c|c|c|c|c|}
\hline \multirow{2}{*}{ No. } & Jenjang & \multicolumn{5}{|c|}{ Persentase Pencapaian } \\
\cline { 3 - 7 } & Sekolah & $50-60 \%$ & $>60-70 \%$ & $>70-80 \%$ & $>80 \%$ & jmlh \\
\hline I. & SD & 0 & 0 & I & 5 & 6 \\
\hline
\end{tabular}

Sedangkan apabila dilihat dari nilai pencapaian untuk delapan standar nasional maka dapat dikemukkaan di sini bahwa untuk satuan pendidikan SD telah mencapai $83.55 \%$. Berdasarkan data pencapaian delapan standar nasional pendidikan tersebut, dapat disimpulkan bahwa satuan pendidikan di Kecamatan Depok Kabupaten Sleman berdasarkan data sampel telah layak mencapat standar nasional pendidikan di atas $70 \%$. Berdasarkan data distribusi Bila dilihat status akreditasi sekolah, dapat dikemukakan di sini bahwa, semakin tinggi status akreditasi sekolah, semakin tinggi pula pencapaian standar nasional pendidikan. Oleh karena itu dapat dikatakan bahwa legalitas hasil akreditasi SD mencerminkan kualitas sekolah. Sekolah Dasar di Kecamatan Depok Kabupaten Sleman menunjukkan pencerminan 
hubungan yang positif antara nilai akreditasi dengan pencapaian standar nasional pendidikan. Adapun peta kelayakan sekolah dapat dilihat pada table 2 sebagai berikut.

Tabel 2

Kelayakan Sekolah Dasar dilihat dari 8 Standar Nasional Pendidikan

\begin{tabular}{|c|l|c|}
\hline No & \multicolumn{1}{|c|}{ Standar } & $\begin{array}{c}\text { Pencapaian 8 Standar } \\
\text { SNP } \\
\text { SD }\end{array}$ \\
\hline 1 & Isi & 86.24 \\
\hline 2 & Proses & 83.89 \\
\hline 3 & Lulusan & 79.22 \\
\hline 4 & Ketenagaan & 89.58 \\
\hline 5 & Sarpras & 71.27 \\
\hline 6 & Pengelolaan & 82.89 \\
\hline 7 & Pembiayaan & 87.97 \\
\hline 8 & Penilaian & 87.34 \\
\hline & & 83.55 \\
\hline
\end{tabular}

\section{Pencapaian Standar Pengelolaan}

Pencapaian setiap indikator pada standar pengelolaan untuk Sekolah Dasar (SD) di Kecamatan Depok Kabupaten Sleman ditunjukkan pada tabel 3 berikut dan gambar I. Tingkat pencapaian yang tertinggi adalah pada indikator pengawasan dan evaluasi $(90.5 \%)$, dan yang terendah adalah indikator Sistem Informasi Manajemen Sekolah (73.0\%) dan Kepemimpinan Sekolah (76.9\%).

Tabel 3

Tingkat Pencapaian Indikator Standar Pengeloaan SD

\begin{tabular}{|l|l|c|}
\hline No & Indikator Standar Pengeloaan & Tingkat Pencapaian \\
\hline I. & Rencana Kerja Sekolah & $85.7 \%$ \\
\hline 2. & Pelaksanaan rencana Kerja Sekolah & $87.5 \%$ \\
\hline 3. & Pengawasan dan Evaluasi & $90.5 \%$ \\
\hline 4. & Kepemimpinan Sekolah & $76.9 \%$ \\
\hline 5. & Sistem Informasi Manajemen Sekolah & $73.0 \%$ \\
\hline Rata-rata & $82.7 \%$ \\
\hline
\end{tabular}

Berdasarkan data tersebut pada umumnya pencapaian standar pengelolaan Sekolah Dasar (SD) di Kecamatan Depok Kabupaten Sleman sudah tercapai yakni semua indikator di atas $70 \%$. Hasil tersebut dapat dilihat lebih jelas pada gambar I berikut ini. 


\section{TINGKAT PENCAPAIAN INDIKATOR STANDAR PENGELOAAN}

\section{SD}

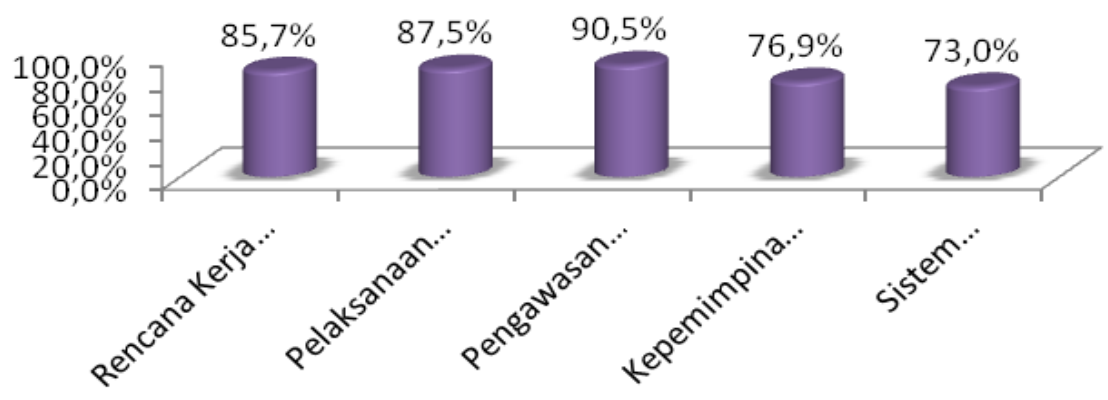

Gambar I. Pencapaian setiap indikator pada standar Pengelolaan SD

\section{Hambatan Pencapaian Standar Nasional Pendidikan}

Hambatan dalam pencapaian 8 standar nasional pendidikan masih ada beberapa hambatan di setiap standar. Waluapun demikian sudah ada usaha-usaha yang dilakukan Sekolah Dasar (SD) di Kecamatan Depok Kabupaten Sleman untuk mengatasi permasalahan yang ada. Adapun keenam SD tersebut adalah SDN Depok I, SDN Caturtunggal I, SDN Babarsari, SDN Gejayan, SDN Condongcatur, dan SDN Kentungan.

Hambatan dan usaha yang dialami sekolah dalam pencapaian Standar pengelolaan pendidikan antara lain belum adanya model standar pengelolaan, petugas pengelolaan yang sesuai dengan keahliannya belum memadai, belum mampu mengelola sistem informasi manajemen yang memadai untuk mendukung administrasi pendidikan, visi, misi, tujuan dan rencana kerja yang sesuai. Usaha yang dilakukan berkoordinasi dengan stakholder khususnya sekolah untuk membuat model pengelolaan sesuai sekolah masing-masing, mensinkronkan antara visi,misi, dan kerja sekolah, merekrut petugas pengelolaan yang mampu mengelola sistem informasi manajemen untuk mendukung.

Secara teoritik, standar pengelolaan merupakan standar nasional pendidikan yang berkaitan dengan perencanaan sekolah, pelaksanaan, dan pengawasan kegiatan pendidikan pada tingkat satuan pendidikan, kabupaten/kota, provinsi, atau nasional agar tercapai efisiensi dan efektivitas penyelenggaraan pendidikan (Mulyasa, 2010: 39). Dalam konteks standar perencanaan, sekolah harus memiliki rencana strategis yang jelas yang akan dicapai dalam jangka panjang (rencana strategis) dan dijadikan acuan dalam rencana operasional. Dalam rencana ini wawasan masa depan (visi) dijadikan pemandu bagi rumusan misi sekolah. Wawasan masa depan atau visi sekolah adalah gambaran masa depan yang dicita-citakan oleh sekolah. Sedangkan misi sekolah merupakan tindakan untuk merealisasikan visi. Visi dan misi dijadikan acuan dalam merumuskan tujuan sekolah, yang merumuskan rumusan hasil yang diharapkan oleh sekolah. Kegiatan sekolah idealnya dilakukan berdasarkan atas tujuan sekolah yang dirumuskan secara jelas. Kriteria utama keunggulan sekolah adalah sejauhmana warga sekolah memahami dan menyadari visi, misi dan tujuan sekolah dan sejauhmana tujuan itu dicapai. Tujuan yang dirumuskan berdasarkan visi dan misi sekolah ini selanjutnya dijadikan acuan dalam penyusunan rencana operasional yang bersifat lebih rinci dan lebih operasional dan memiliki standar operasional yang jelas.

Pertama adalah komponen perencanaan. Setiap satuan pendidikan dikelola atas dasar rencana kerja tahunan yang merupakan penjabaran rinci dari rencana kerja jangka menengah satuan pendidikan yang meliputi empat (4) tahun. Untuk jenjang pendidikan dasar dan menengah, rencana kerja tahunan harus disetujui oleh rapat dewan pendidik setelah memperhatikan pertimbangan dewan komite. Adapun standar yang digunakan dalam 
akreditasi sekolah adalah: sekolah memiliki rencana strategis dengan rumusan visi, misi, dan tujuan yang jelas dan dipahami oleh setiap warga sekolah, yang digunakan sebagai acuan bagi pengembangan rencana operasional dan program sekolah. Rencana sekolah secara jelas menggambarkan tentang hasil yang akan dicapai, terutama kompetensi lulusan, dalam jangka pendek, menengah, dan panjang yang dipahami oleh seluruh pihak-pihak yang berkepentingan dengan sekolah (stakeholders), baik oleh warga sekolah maupun masyarakat yang terkait dengan sekolah secara jelas dan terukur.

Komponen kedua adalah komponen pelaksanaan. Komponen Pelaksanaan ini menekankan pada manajemen sekolah. Manajemen sekolah merupakan pengelolaan sekolah yang dilakukan dengan dan melalui sumberdaya manusia untuk mencapai tujuan sekolah secara efektif dan efisien. Dua hal yang merupakan inti dari manajemen sekolah adalah aspek dan fungsi. Manajemen dipandang sebagai aspek meliputi kurikulum, tenaga/sumberdaya manusia, siswa, sarana dan prasarana, dana, dan hubungan masyarakat. Manajemen dipandang sebagai fungsi meliputi pengambilan keputusan, pemformulasian tujuan, perencanaan, pengorganisasian, pengaturan ketenagaan, pengkomunikasian, pelaksanaan, pengkoordinasian, supervisi, dan pengendalian (Depdiknas, 200I: 14). Dengan pola pemikiran manajemen sekolah yang meliputi aspek dan fungsi seperti tersebut diatas, maka manajemen sekolah meliputi semua fungsi yang diterapkan pada semua aspek sekolah. Artinya, sekolah menerapkan pengambilan keputusan, perumusan tujuan, perencanaan, pengorganisasian, pengaturan ketenagaan, pengkomunikasian, pelaksanaan, pengkoordinasian, supervisi, dan pengendalian pada semua aspek sekolah yang terdiri dari kurikulum, tenaga atau sumberdaya manusia, siswa, sarana dan prasarana, dana, dan hubungan masyarakat secara sistemik dan sistematik.

Manajemen sekolah tersebut merupakan manajemen berpusat pada sekolah atau yang dikenal dengan manajemen berbasis sekolah (MBS). MBS adalah suatu model manajemen yang bertolak dari kemampuan, kesanggupan, dan kebutuhan sekolah, dan bukannya perintah serta petunjuk dari lapisan birokrasi atasan, dengan catatan bahwa apa yang dilakukan oleh sekolah harus tetap dalam koridor kebijakan pendidikan nasional. Oleh karena itu, MBS membolehkan adanya keragaman dalam pengelolaan sekolah yang didasarkan atas kekhasan dan kemandirian sekolah itu sendiri. Dalam MBS, semua kegiatan harus dikaitkan dengan tujuan yang akan dicapai oleh sekolah (peningkatan kualitas, produktivitas, efektivitas, efisiensi, relevansi, dan inovasi) dan dilakukan menurut prinsip-prinsip MBS yang antara lain meliputi kemandirian, kemitraan/partisipasi, semangat kebersamaan, tanggungjawab, transparansi/keterbukaan, keluwesan/ fleksibilitas, akuntabilitas, dan keberlanjutan. Mengingat MBS berprinsip pada partisipasi masyarakat dalam penyelenggaraan pendidikan, maka pelibatan masyarakat melalui wadah yang disebut Komite Sekolah merupakan upaya yang harus dilakukan oleh sekolah. Tingkat partisipasi masyarakat dapat dilihat dari besar kecilnya dukungan mereka terhadap sekolah, baik berupa finansial, moral, jasa (pemikiran, keterampilan), dan barang/benda. Mengingat uniknya prinsip-prinsip MBS tersebut, maka diperlukan seorang kepala sekolah yang memiliki sifat-sifat sebagai manajer profesional (Depdiknas, 200I: 15).

Adapun standar yang digunakan dalam akreditasi sekolah adalah: manajemen sekolah dilaksanakan menurut aspek dan fungsi manajemen secara utuh. Aspek-aspek manajemen sekolah yang dimaksud meliputi kurikulum, tenaga/sumberdaya manusia, siswa, sarana dan prasarana, dana, dan hubungan masyarakat. Ada bukti-bukti yang menunjukkan bahwa sekolah menerapkan manajemen berbasis sekolah yang dibuktikan oleh penerapan prinsipprinsip manajemen berbasis sekolah yaitu kemandirian, kemitraan/partisipasi, semangat kebersamaan, tanggungjawab, transparansi atau keterbukaan, keluwesan atau fleksibilitas, akuntabilitas, dan sustabilitas atau keberlanjutan. 
Ketiga adalah komponen pengawasan. Pengawasan merupakan salah satu fungsi penting dalam manajemen sekolah. Pengawasan satuan pendidikan meliputi pemantauan supervisi, evaluasi, pelaporan, dan tindak lanjut hasil pengawasan. Pemantauan dilakukan oleh pemimpin satuan pendidikan dan komite sekolah/madrasah atau bentuk lain dari lembaga perwakilan pihak-pihak yang berkepentingan secara teratur dan berkesinambungan untuk menilai efisiensi, efektivitas, dan akuntabilitas satuan pendidikan (Mulyasa, 20I0: 40). Supervisi yang meliputi supervisi manajerial dan akademik dilakukan secara teratur dan berkesinambungan oleh pengawas atau penilik satuan pendidikan dan kepala satuan pendidikan. Pelaporan hasil pengawasan dilakukan oleh pendidik, tenaga kependidikan, pimpinan satuan pendidikan, dan pengawas atau penilik satuan pendidikan. Setiap pihak yang menerima laporan hasil pengawasan wajib menindaklanjuti hasil laporan tersebut untuk meningkatkan mutu satuan pendidikan, termasuk memberikan sangsi atas pelanggaran yang ditemukannya. Dalam pelaksanaan pengawasan ini terkandung pula fungsi pemantauan yang diarahkan untuk melihat apakah semua kegiatan berjalan lancar dan semua sumber daya dimanfaatkan secara optimal, efektif dan efisien. Pengawasan dan monitoring dilakukan secara berkala dan tepat sasaran sehingga hasilnya dapat digunakan untuk melakukan perbaikan. Adapun Standar yang digunakan adalah: ada bukti-bukti yang menunjukkan bahwa sekolah melaksanakan fungsi pemantauan dan pengawasan secara berkala termasuk pada kegiatan pembelajaran di kelas yang hasilnya digunakan untuk perbaikan-perbaikan secara berkelanjutan. Standar pengelolaan dikatakan efektif jika memuat komponen perencanaan sekolah, pelaksanaan, dan pengawasan kegiatan pendidikan pada tingkat satuan pendidikan, kabupaten/kota, provinsi, atau nasional.

Standar pengelolaan menurut Peraturan Pemerintah Republik Indonesia Nomor 32 Tahun 2013 tentang Perubahan Atas Peraturan Pemerintah Nomor 19 Tahun 2005 tentang Standar Nasional Pendidikan adalah kriteria mengenai perencanaan, pelaksanaan, dan pengawasan kegiatan pendidikan pada tingkat satuan pendidikan, kabupaten/kota, provinsi, nasional agar tercapai efisiensi dan efektivitas penyelenggaraan pendidikan. Standar Pengelolaan Pendidikan diatur dalam Peraturan Pemerintah No.19 Tahun 2005 tentang Standar Nasional Pendidikan dan tidak mengalami perubahan pada Peraturan Pemerintah No.32 Tahun 2013 tentang Perubahan Peraturan Pemerintah No. 19 Tahun 2006. Secara rinci Standar Pengelolaan Pendidikan diatur di dalam Peraturan Menteri Pendidikan NasionalNomor 19 Tahun 2007 tentang Standar Pengelolaan Pendidikan oleh Satuan Pendidikan Dasar dan Menengah.

Berdasarkan Peraturan Menteri Pendidikan Nasional Nomor 19 Tahun 2007 tentang Standar Pengelolaan Pendidikan oleh Satuan Pendidikan Dasar dan Menengah, pengelolaan atau manajemen sekolah dibagi ke dalam enam hal utama, yaitu : Perencanaan Program, Pelaksanaan Rencana Kerja, Pengawasan dan Evaluasi, Kepemimpinan Sekolah/Madrasah, Sistem Informasi dan Manajemen, dan Penilaian Khusus. Standar pengelolaan adalah standar nasional pendidikan yang berkaitan dengan perencanaan sekolah, pelaksanaan, dan pengawasan kegiatan pendidikan pada tingkat satuan pendidikan, kabupaten/kota, provinsi, atau nasional agar tercapai efisiensi dan efektivitas penyelenggaraan pendidikan (Mulyasa, 2010: 39). Dalam konteks standar perencanaan, sekolah harus memiliki rencana strategis yang jelas yang akan dicapai dalam jangka panjang (rencana strategis) dan dijadikan acuan dalam rencana operasional. Dalam rencana ini wawasan masa depan (visi) dijadikan pemandu bagi rumusan misi sekolah. Wawasan masa depan atau visi sekolah adalah gambaran masa depan yang dicita-citakan oleh sekolah. Sedangkan misi sekolah merupakan tindakan untuk merealisasikan visi. Visi dan misi dijadikan acuan dalam merumuskan tujuan sekolah, yang merumuskan rumusan hasil yang diharapkan oleh sekolah.

Kegiatan sekolah idealnya dilakukan berdasarkan atas tujuan sekolah yang dirumuskan secara jelas. Kriteria utama keunggulan sekolah adalah sejauhmana warga 
sekolah memahami dan menyadari visi, misi dan tujuan sekolah dan sejauhmana tujuan itu dicapai. Tujuan yang dirumuskan berdasarkan visi dan misi sekolah ini selanjutnya dijadikan acuan dalam penyusunan rencana operasional yang bersifat lebih rinci dan lebih operasional dan memiliki standar operasional yang jelas. Pertama adalah komponen perencanaan. Setiap satuan pendidikan dikelola atas dasar rencana kerja tahunan yang merupakan penjabaran rinci dari rencana kerja jangka menengah satuan pendidikan yang meliputi empat (4) tahun. Untuk jenjang pendidikan dasar dan menengah, rencana kerja tahunan harus disetujui oleh rapat dewan pendidik setelah memperhatikan pertimbangan dewan komite. Adapun standar yang digunakan dalam akreditasi sekolah adalah: sekolah memiliki rencana strategis dengan rumusan visi, misi, dan tujuan yang jelas dan dipahami oleh setiap warga sekolah, yang digunakan sebagai acuan bagi pengembangan rencana operasional dan program sekolah. Rencana sekolah secara jelas menggambarkan tentang hasil yang akan dicapai, terutama kompetensi lulusan, dalam jangka pendek, menengah, dan panjang yang dipahami oleh seluruh pihak-pihak yang berkepentingan dengan sekolah (stakeholders), baik oleh warga sekolah maupun masyarakat yang terkait dengan sekolah secara jelas dan terukur.

Komponen kedua adalah komponen pelaksanaan. Komponen Pelaksanaan ini menekankan pada manajemen sekolah. Manajemen sekolah merupakan pengelolaan sekolah yang dilakukan dengan dan melalui sumberdaya manusia untuk mencapai tujuan sekolah secara efektif dan efisien. Dua hal yang merupakan inti dari manajemen sekolah adalah aspek dan fungsi. Manajemen dipandang sebagai aspek meliputi kurikulum, tenaga/sumberdaya manusia, siswa, sarana dan prasarana, dana, dan hubungan masyarakat. Manajemen dipandang sebagai fungsi meliputi pengambilan keputusan, pemformulasian tujuan, perencanaan, pengorganisasian, pengaturan ketenagaan, pengkomunikasian, pelaksanaan, pengkoordinasian, supervisi, dan pengendalian (Depdiknas, 200I: 14). Dengan pola pemikiran manajemen sekolah yang meliputi aspek dan fungsi seperti tersebut diatas, maka manajemen sekolah meliputi semua fungsi yang diterapkan pada semua aspek sekolah. Artinya, sekolah menerapkan pengambilan keputusan, perumusan tujuan, perencanaan, pengorganisasian, pengaturan ketenagaan, pengkomunikasian, pelaksanaan, pengkoordinasian, supervisi, dan pengendalian pada semua aspek sekolah yang terdiri dari kurikulum, tenaga atau sumberdaya manusia, siswa, sarana dan prasarana, dana, dan hubungan masyarakat secara sistemik dan sistematik. Berdasarkan uraian di atas sekolah yang efektif dengan kualitas manajemen yang baik ditandai oleh beberapa indikator sebagai berikut : (I) efektivitas belajar dan pembelajaran yang tinggi; (2) kepemimpinan yang kuat dan demokratis; (3) manajemen tenaga kependidikan yang efektif dan profesional; (4) tumbuhnya budaya mutu; serta (5) teamwork yang cerdas, kompak dan dinamis.

\section{KESIMPULAN}

Pencapaian setiap indikator pada standar pengelolaan untuk Sekolah Dasar (SD) di Kecamatan Depok Kabupaten Sleman tingkat pencapaian yang tertinggi adalah pada indikator pengawasan dan evaluasi (90.5\%), dan yang terendah adalah indikator Sistem Informasi Manajemen Sekolah (73.0\%) dan Kepemimpinan Sekolah (76.9\%). Hambatan dan usaha yang dialami sekolah dalam pencapaian Standar pengelolaan pendidikan antara lain belum adanya model standar pengelolaan, petugas pengelolaan yang sesuai dengan keahliannya belum memadai, belum mampu mengelola sistem informasi manajemen yang memadai untuk mendukung administrasi pendidikan, visi, misi, tujuan dan rencana kerja yang sesuai. Usaha yang dilakukan berkoordinasi dengan stakholder khususnya sekolah untuk membuat model pengelolaan sesuai sekolah masing-masing, mensinkronkan antara visi,misi, dan kerja sekolah, merekrut petugas pengelolaan yang mampu mengelola sistem informasi manajemen untuk mendukung. 
Masukkan bagi dinas pendidikan untuk meningkatkan kebijakan strategis terhadap SD agar pencapaian estándar pengelolaan bisa tercapai secara optimal. Saran juga untuk pengawas sekolah dan kepala sekolah untuk terus meningkatkan kinerja sekolah untuk pencapaian tingkat stándar nacional pendidikan secara lebih baik.

\section{DAFTAR PUSTAKA}

Anderson, Lorin W. 2004. Increasing Teacher Effectiveness $2^{\text {nd }}$ Edition. Paris: UNESCO International Institute for Educational Planning.

Bryson, JM. 2004. Strategic Planning for Public and Nonprofit Organizations. $3^{\text {rd }}$ edition. San Fransisco: Jossey-Bass Publishers.

http://www.mitrainvestor.com/blog/2013/03/I8/human-development-index-indonesianomor-I2I-tingkat-dunia/. "Human Development Index Indonesia Nomor 121 Tingkat Dunia". Posted on 18 March 2013. Visited: 28 Februari 2014.

Hay McBer. 2000. Research into Teacher Effectiveness: A Model of Teacher Effectiveness (Research Report, No. 216). Norwich: The Crown Copyright Unit.

Nye, B., S. Konstantopoulos, dan L.V. Hedges. 2004. "How Large are Teacher Effects?".Educational Evaluation and Policy Analysis, 26 (3), 237-257.

Sallis, Edward, 2010, Total Quality Management in Education, (Terjemahan), Ircisod, Yogyakarta. Schalock, H.D., M.D. Schalock, B. Cowart, dan D. Myton. 1993. "Extending Teacher Assessment Beyond Knowledge and Skills: An Emerging Focus on Teacher Accomplishments". Journal of Personnel Evaluation and Education, 7, I05-133

Sallis, Edward, 2010, Total Quality Management in Education, (Terjemahan), Ircisod, Yogyakarta. Tucker, P.D., dan J.H. Stronge. 200I. "The Ultimate Accountability: Use of Student Learning Measures in Teacher Evaluation”. American School Board Journal, 9, 34-37.

Teacher Evaluation 2.0 dalam www.tntp.org

Roy Barnes. (2005). Moving towards technology education : Factors that facilitated teachers' implementation of a technology curriculum. Journal of Technology Education. 17 (I), 6 $-18$.

Carolin Rekar Munro. (2005). "Best Practices" in teaching and learning : Challenging current paradigms and redefining their role in education. The College Quarterly. 8

Departemen Pendidikan Nasional. (200I). Manajemen Peningkatan Mutu Berbasis Sekolah. Jakarta: Ditjen Dikdasmen Depdiknas.

Departemen Pendidikan dan Kebudayaan. (2013). Peraturan Menteri Pendidikan dan Kebudayaan No 96 Tentang Badan Standar Nasional Pendidikan. Jakarta: Ditjen Dikdasmen Depdiknas.

Madus, G. E., \& Kellaghan, T. (20I2). Curriculum evaluation and assessment in Jackson, P. M. (Edit, 1992). Handbook of research on curriculum. New York: McMillan Publishing Company.

Morrison, D.M. \& Mokashi K. \& Cotter, K. (2006). Instructional quality indicators: Research foundations. Cambrigde. Diambil pada tanggal 17 Februari 2006 dari www.co.nect.net

Nitko, A. J. (1996). Curriculum-based assessment. Jakarta: Ministery of Education and Culture.

(Standards for curricula and assessment systems (C) 2010 General Medical Council (www.cdc.gov/healthyouth/evaluation) .

Alma, Buchori dan Hurriyati, Ratih, 2009, Manajemen Corporate dan Strategi Pemasaran Jasa Pendidikan, Fokus pada Mutu dan Layanan Prima, Alfabeta, Bandung.

Anderson, Lorin W. 2004. Increasing Teacher Effectiveness $2^{\text {nd }}$ Edition. Paris: UNESCO International Institute for Educational Planning.

Bahan TOT Kurikulum 2013, Kemdikbud Bastanfar, Ali. Alternatives in Assessment dalam http://www3.telus.net/linguisticissues/alternatives 
Brown, Abbie and Green, Timothy D. 2006. The Essentials of Instructional Design 'connecting fundamental principles with process and practice, New Jersey: Pearson Prentice Hall.

Bryson, JM. 2004. Strategic Planning for Public and Nonprofit Organizations. $3^{\text {rd }}$ edition. San Fransisco: Jossey-Bass Publishers.

Bush, Tony and Marianne Coleman. 2012. Manajemen Mutu Kepemimpinan Kependidikan. Yogyakarta: IRCISod.

Danim, Sudarwan, 2005, Menjadi Komunitas Pembelajar, Bumi Aksara, Jakarta

Darling-Hammond, L. 2000. "Teacher Quality and Student Achievement: A Review of State Policy Evidence”. Educational Policy Analysis Archives, 8 (I).

Hamid, Hamdani, 2013, Pengembangan Sistem Pendidikan di Indonesia, Pustaka Setia, Bandung

Hay McBer. 2000. Research into Teacher Effectiveness: A Model of Teacher Effectiveness

(Research Report, No. 216). Norwich: The Crown Copyright Unit.

http://anomsblg.wordpress.com/profesi-kependidikan/standar-pembiayaan-pendidikan/ diakses tanggal I0 Maret 2014 pukul 14.00

http://dinarpratama.wordpress.com/2010/I I/28/perbedaan-pengertian-examinationassessment-measurement-dan-evaluation

http://www.enotes.com/ref/g-and-a/distinction-between-assessment-evaluation-20||3|

Kizlik, Bob. Measurement, Assessment, and Evaluation in Education dalam http://www.adprima.com/measurement.htm

Makbulloh, Deden, 201 I, Manajemen Mutu Pendidikan Islam, Raja Grafindo, Jakarta

Mulyasa H.E, 2012, Manajemen Kepemimpinan Kepala Sekolah, Bumi Aksara, Jakarta

Nye, B., S. Konstantopoulos, dan L.V. Hedges. 2004. "How Large are Teacher Effects?". Educational Evaluation and Policy Analysis, 26 (3), 237-257.

Orstein, Allan C. and Hunkins Francis P. 1993. Curriculum 'foundations, principles and issues', Boston: Allyn and Bacon.

Peraturan Pemerintah No. 19 Tahun 2006 tentang Standar Nasional Pendidikan

Peraturan Pemerintah No.32 Tahun 2013 tentang Perubahan Peraturan Pemerintah No. 19 Tahun 2005

Pidarta, Made, 20I I, Manajemen Pendidikan Indonesia, Rineka Cipta, Jakarta

Richard, Jack C. 200I. Curriculum Development in Language Teaching, Cambridge: Cambridge University Press.

Sallis, Edward. 2012. Total Quality Management in Education. Yogyakarta: IRCISod.

Sanders, W.L. dan J.C. Rivers. 1996. Cumulative and Residual Effects of Teachers on Future Student Academic Achievement. Knoxville: University of Tennessee Value-Added Research and Assessment Center.

Schalock, H.D., M.D. Schalock, B. Cowart, dan D. Myton. 1993. "Extending Teacher Assessment Beyond Knowledge and Skills: An Emerging Focus on Teacher Accomplishments". Journal of Personnel Evaluation and Education, 7, 105-133.Teacher Evaluation 2.0 dalam www.tntp.org

Tucker, P.D., dan J.H. Stronge. 200I. "The Ultimate Accountability: Use of Student Learning Measures in Teacher Evaluation”. Amerian School Board Journal, 9, 34-37.

Umiarso dan Gojali, Imam, 2010, Manajemen Mutu Sekolah di Era Otonomi Pendidikan, Ircisod, Yogyakarta.

Virginia Board of Education. 2012. Guidelines for Uniform Perfomance Standards and Evaluation Criteria for Teachers. Virginia: Virginia Department of Education.

Wahyudi, 20II, Manajemen Kepemimpinan Kepala Sekolah pada Organisasi Pembelajaran, Rajagrafindo, Jakarta

Chatib, M. 2012. Multiple Intelligences Menurut Prespektif Munif Chatib. http:/ /munifchatib.wordpress.com/20I2/I I/I //multiple-intelligences-menurut-prespektifunif-chatib/. Posted by: munifchatib, 19 November 2012. Visited: 27 Februari 2014. 
http://www.mitrainvestor.com/blog/2013/03/I8/human-development-index-Indonesia-morI2I-tingkat-dunia/. "Human Development Index Indonesia Nomor I2I Tingkat Dunia". Posted on 18 March 2013. Visited: 28 Februari 2014.

http://www.eurocham.or.id/joomla/index.php?option=com_content\&view=article\&id=383:do ing-business-in-indonesia-regional-data-for-2010-a-20 I \&catid=83:datastatistics\&ltemid $=213$.

“Indonesia's Rank \& Score: The Global Competitivebess Report 2012-20I3”. Visited: 28 Februari 2014 http://www.antaranews.com/berita/407677/mendikbud-ada-kaitanutuh-antara-kurikulum-20I3-dengan-ujian-nasional. Posted on 02 Desember 2013. Visited: 28 Februari 2014. 